\title{
The Meaning of Water in Javanese Padusan and Japanese Misogi-Harai Rituals
}

\author{
Dwiana Retno Yulianti ${ }^{1 *}$, Sriwahyu Istana Trahutami ${ }^{1}$, and Reny Wiyatasari ${ }^{1}$ \\ ${ }^{1}$ Japanese Language and Culture Study Program, Faculty of Humanities, Diponegoro University, \\ Semarang-Indonesia
}

\begin{abstract}
Indonesia and Japan are two countries known for their high regard for culture and tradition, with no exception for those associated with religious rituals. In Japan, the Shinto religion is highly renowned for being the existing and believed ancestor religion. Meanwhile, in Indonesia, Islam is the largest religion that has indirectly influenced the cultures and traditions developed in society. Both Islam and the Shinto have a purification ritual with water as their medium, Padusan and Misogi-Harai, respectively. This study focuses on three things, i.e., the history, time of performance, and ritual procedure, to examine the corresponding meaning of the water as the media in both rituals. The method used to collect data is the literature study, and the data is then analyzed using the qualitative content analysis method. As a result of the three aspects studied, two similar meanings of water to the ritualistic purpose were discovered, i.e., purifying the soul from impurities/sin and returning the spirit to devotion to God.
\end{abstract}

\section{Introduction}

Javanese and Japanese people are known for upholding their cultures and traditions. Many traditions and rituals have developed in both countries, one of which is water as a medium. The choice of water as a media ritual is certainly not without purpose, but it contains many meanings, as does the existence of water as a source of life. Furthermore, because Indonesia and Japan are archipelagic states with abundant water resources, water as a ritual medium is not taboo. However, in the modern era, many young people do not understand the meaning of the rituals they perform, including using water as a ritual medium. This is a problem because culture has lost its meaning, and the younger generation cannot learn something worthwhile from it. Furthermore, culture will be lost, resulting in the loss of national identity.

Aside from the issue of cultural sustainability, another issue that can arise as a result of the community's loss of culture and tradition is environmental sustainability. It is interconnected, so if one is lost, the other will also be lost. For example, a tradition performed in specific locations such as rivers, seas, or other water sources will almost certainly be kept clean and sustainable so that it is not harmed or lost. Tradition cannot be carried out if the water source is contaminated, such as with murky water. Similarly, if the community. loses

\footnotetext{
* Corresponding author: yuliantidwiana@gmail.com
} 
and forgets tradition, it is possible that the existence of places such as water sources will also be forgotten and lost.

Out Out of the many traditions in both countries, this study will only focus on the padusan ritual in Java and the misogi-harai ritual in Japan. Both were chosen because they are thought to be comparable in that they are both bathing rituals using water as the medium.

The padusan ritual is a soul-cleansing ritual conducted in Java to welcome the holy month of Ramadan. The padusan initially comes from the word 'adus,' which means bathing. The rite is performed in large groups in various locations, such as a river, a pool, and a bathroom. Ignoring the fact that padusan is a bathing ritual, the hair on the head is the central body part that gets cleansed. According to Tok Suwarto, as quoted from Quinn [1], hair washing or cleansing has the purpose of being a physical and spiritual preparation to clear, clean, and sanctify the mind so that when the Fast begins, you are not distracted by base appetites. Most Javanese people carry out Padusan tradition, but the obligation depends on their respective regions.

Shinto people in Japan have a ritual called misogi-harai, which is similar to the padusan ritual. Etymologically, harai means 'purification' while misogi means 'ablution'. In terms of etymology, harai or harae is the generic name for the act of ritual purification to remove impurities, of which there are several forms [2]. Moreover, misogi is a ritual of selfpurification performed under the waterfall. However, it also does not close the possibility that misogi is also done by the sea, river, or unique ponds [2].

Padusan and misogi-harai rituals appear to be comparable at first glance in terms of their definitions and use of water as a ritual medium. This study focuses on three aspects: history, performance time, and padusan and misogi-harai ritual procedures. The ritual procedure can indicate how the water media plays a role in the ritual, and the history of the ritual and the timing of performance can define how the ritual began and why it should be performed. The problem formulation in this study is the similarity of the meaning of water media utilized in both rituals by analyzing these three aspects.

\section{Method}

This This research is a literature review. Documentation, such as books, journals, websites, and pertinent papers, is used to source data. The collected data is analyzed using qualitative content analysis. The content analysis entails inspection of the data for recurrent instances of some kinds, irrespective of the type of instance (e.g., word, phrase, some more significant meaning) [3]. The data is presented in a qualitative descriptive manner. The conclusion section will be brief but comprehensive, covering all aspects of data analysis.

In this study, two literature reviews were used. The first is a study entitled Pandangan Masyarakat mengenai Tradisi Padusan, which was conducted by Widyastutik [4]. She concluded in her study that the padusan tradition attempts to cleanse or purify the soul symbolically before fasting. The ritual of padusan is examined in this study, which is identical to a previous study. However, this study focuses on comparing the meaning of water as a medium in padusan and misogi-harai rituals.

Pratiwi [5] conducted a study entitled Harai: Telaah Konsep Religi Koentjaraningrat, the second literature review. She found that Japanese people face God with a pure soul and body because they believe that because humans are born pure, they must live in chastity. This study is similar to the preceding one in that it discusses misogi rituals as a type of harai. However, the focus of this study is on the similarity in meaning of water media utilized in two different rituals, padusan and misogi-harai. 


\section{Results and Discussion}

\subsection{Padusan Ritual in Java}

\subsubsection{History of Javanese Padusan}

Padusan Padusan ritual was initially developed from Hindu, Buddhist, and Animism civilizations, which were the beliefs of Indonesian ancestors, despite its Islamic nuances. It was utilized as a method of self-purification by knights, poets, brahmins, and masters throughout the Majapahit Kingdom. In addition, ascetics and kings who wish to meditate must first execute the padusan ritual to purify their souls and bodies of impurities that can lead to sin. The ascetics and kings are expected to bring ubarampe (requirements) that have been determined, such as to scents, incense, seven flowers in various forms, etc., for the ceremony performed the day before the meditation.

After the entrance of Walisongo, a character who preached Islam in Java, the culture of the existing ancestral beliefs was mated with Islamic culture. The goal of the marriage of the two cultures is to preserve society's culture while being true to Islamic principles. This is also one of Walisongo's strategies for peacefully introducing Islam. The strategies would not terrify Indonesians, who were formerly Hindus and Buddhists. According to Islamic principles, rituals that were earlier embellished with frankincense and mantras are now abolished because they can cause shirk. In addition to removing some parts, Walisongo also added some new ones to the ritual, such as Islamic-inspired prayers.

Padusan ritual became a routine activity of the community when it came to welcoming the holy month of Ramadan after being mated with Islamic teachings and culture by the Walisongo. The ritual is widely performed in the spring, also known as umbul, or in a pool near the mosque. Women and men do not bathe together in the pool to avoid violating Islamic beliefs on separating male and female body parts that should not be seen with each other.

Looking at the historical side, the padusan ritual appears to have shifted in this day and age, both in terms of meaning and implementation procedures. Nowadays, many people perform the padusan ritual, but they break the rules, especially by mixing men and women in the same pool. Furthermore, padusan, which used to be a means of cleaning away the soul's dirt, is now interpreted by many as a form of entertainment before welcoming Ramadan.

Despite the shift in meaning, padusan rituals are still practised, one of which is to protect the environment as a form of gratitude to God. The sites where padusan rituals are performed will be kept clean and preserved to preserve their sanctity. Even some padusan ritual implementation sites are considered sacred and should not be tainted because it will result in disaster. With society's assumption about the sacredness of a water source, myths that develop in the community are on the rise. The myth of the ghost of the guardian of sendang (spring) is one of the most well-known in the country.

The spread of these myths appears to positively impact the sustainability of nature, one of which is the protection of water sources from human-caused damage. Because of the sendang's guardian's ghost myth, no one will dare to cause damage or immorality near it [6]. As a result, the availability of clean and clear water sources can assist the community in meeting its needs without causing it damage. 


\subsubsection{Padusan Time of Performance}

Padusan ritual is practised in almost every region of Central Java province and some areas of East Java. Although performed in different locations, the ritual is performed on the same day each year, one day before Ramadan in the afternoon.

\subsubsection{Padusan Ritual Procedure}

There are differences in customs and traditions cause the padusan ritual procedure in one region to differ from those in another. The following is the procedure for implementing padusan in Boyolali, Central Java.

Kirab

The ritual began with participants' execution of the kirab (carnaval), including Taman Pendidikan Al Quran (TPQ) students, marching bands, and rows of kereta kencana. The kirab cavalcade begins at the Banyudono sub-district office and ends at the bathing spot, a relic of Keraton Kasunanan Surakarta Hadiningrat. The procession's purpose is to accompany Mas and Mbak, who will later represent the padusan ritual's opening ceremony.

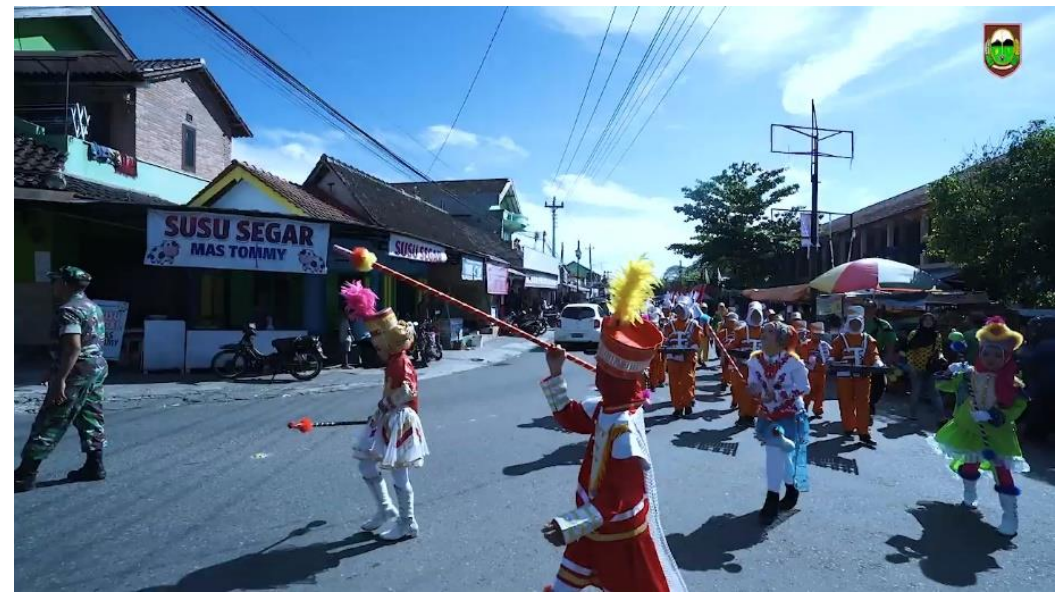

Documentation: youtube.com/Diskominfo Boyolali

Fig.1. Marching bands in the Kirab procession [7].

\section{Siraman Ndalem}

Siraman ndalem begins with the accompaniment of ciblon music or water music played by the youths in the pool. Furthermore, the mas and mbak couples who have become a symbol of the beginning of the padusan ritual are watered with water taken from the keraton heritage pool's spring. This procession has significance as a form of self-purification from past sins and to improve the intention of welcoming the month of Ramadan. Furthermore, the procession is intended to ask God for blessings. 


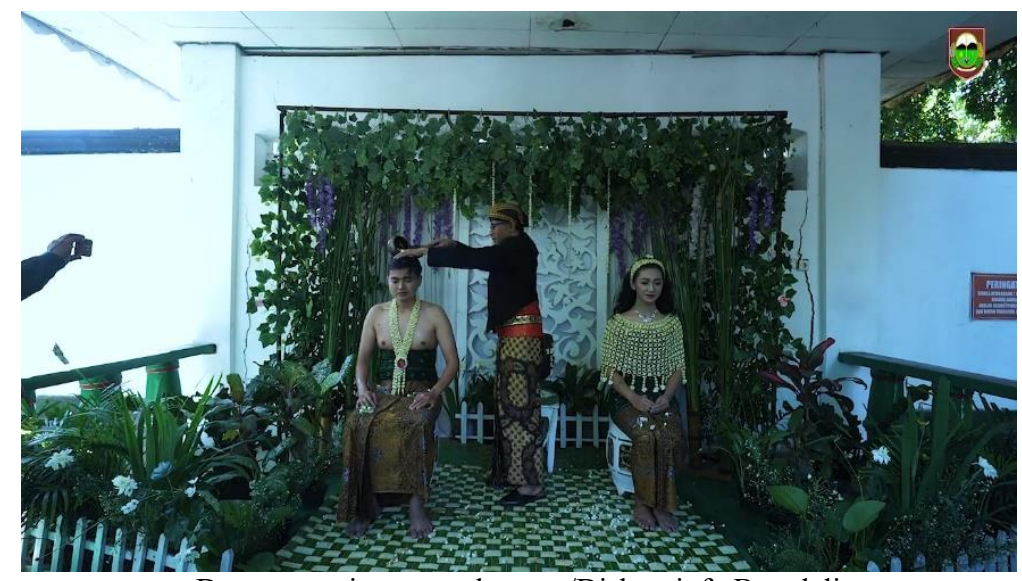

Documentation: youtube.com/Diskominfo Boyolali

Fig. 2. Siraman Ndalem procession in keraton heritage pool's spring.

In contrast to Boyolali, the padusan ritual in Klaten does not have an official opening ceremony. Padusan ritual is only performed by bathing in umbul (pool) to purify the body and soul, as well as restoring the spirit when worshipping God during Ramadan

\subsection{Misogi-Harai Ritual in Japan}

\subsubsection{History of Japanese Misogi-Harai}

Japan Japan is known for its self-purification rituals, which are still practised today. These rituals are the result of beliefs related to the God theory in Japanese mythology. The Japanese considered their land to be endowed by God and directly ruled by God (kami no kuni).

As described in Nihongi and Nihon Shoki, Misogi rituals begin with the story of the Gods who founded the Japanese archipelago, Izanami no Mikoto and Izanagi no Mikoto. They met, procreated, and created islands. Izanami no Mikoto died and went to the land of the dead (yomi no kuni) after giving birth to her son, the God of Fire. Izanami stated that the first time she visited yomi no kuni, it appeared dirty and polluted. Izanagi no Mikoto, who was saddened by the loss, pursued Izanami to yomi no kuni. In that place, he was pursued by ominous-looking creatures. He managed to escape the creature and return to the world.

After returning from yomi no kuni, he found himself dirty because he had entered the polluted land and been chased by a bad-looking creature. As a result of this, he bathed in the Tachibana River to cleanse himself. The self-purification of Izanagi no Mikoto on the Tachibana River is recorded to be the first misogi ritual practice.

Death, which is one of the sources of tsumi (impurity) in Shinto mythology and belief in Japan, can impede the power of kami. The kami cannot give his strength until the place of worship and the worshippers' souls have been cleansed of tsumi. As a result, misogi removes tsumi from the body and Shinto places of worship.

The history of misogi in the form of self-purification using water media and being performed as a ritual brings its own culture to the Japanese people. That is the custom of the entire family, who will take a bath in the river after the funeral. Although it was initially performed in the river, the misogi ritual is frequently performed in the sea and under waterfalls. 
Misogi is not only a ritual of purification from the dirt of the afterlife, but it also has another meaning. Shigenori Hirobe in Pratiwi [5] writes that Japanese people have long believed that rivers, seas, and other bodies of water have guardians, who are kami (God) and other beings. They can salute the creatures in the area by performing misogi. They will also protect these locations and keep their status as holy places sacred.

Misogi ritual is now required for Shinto priests who wish to devote themselves to kami (God). In addition, Nishida Nagano in Picken [8] also explains that ritual called harai and misogi is necessary for preparations for matsuri (festival).

\subsubsection{Misogi-Harai Time of Performance}

Misogi-harai ritual is not performed at all shrines at the same time. Misogi rituals, for example, are performed once a month from April to October at Takekoma Shrine in Miyagi Prefecture. The ritual will begin at 7:00 a.m. local time. Misogi is not required to be performed by a Shinto priest at that shrine, but it is a recommended ritual. According to Haikal, [9] initially, all priests participated in misogi, but the number of priests practising misogi has decreased over the last ten years. Although misogi is performed once a month, the ritual is not performed from November to March due to the winter season and the preparation required for the new year.

In addition to Takekoma Shrine, misogi is also performed at Tsubaki Grand Shrine in Mie Prefecture, on the 11 th of every month, including winter. The ritual is performed under a waterfall late at night or early in the morning. The waterfall is located in the shrine area, close to the main building. Unlike the misogi at Takekoma Shrine, performed in the bathtub with a water dipper, the misogi at Tsubaki Grand Shrine is almost like meditation because it is performed while standing beneath the waterfall. Misogi is a purification ritual with deep meaning for worshipers in Tsubaki Grand Shrine. They can unite with nature and communicate with the kami by performing this ritual.

\subsubsection{Misogi-Harai Ritual Procedure}

Participants should prepare their bodies and souls before beginning the ritual. They are not advised to consume meat, alcohol, or anything else that may impair their senses. When the participants' bodies and souls are ready to perform the ritual, they gather in front of the shrine office before beginning the purification processes.

Tsubaki Grand Shrine's misogi ritual is performed under a waterfall, which is also considered kami. Therefore, before entering the waterfall area, participants should perform a simple purification ritual called Haiden. Following that, men should wear a white loincloth and hachimaki (headband), and women should wear a white kimono and hachimaki.

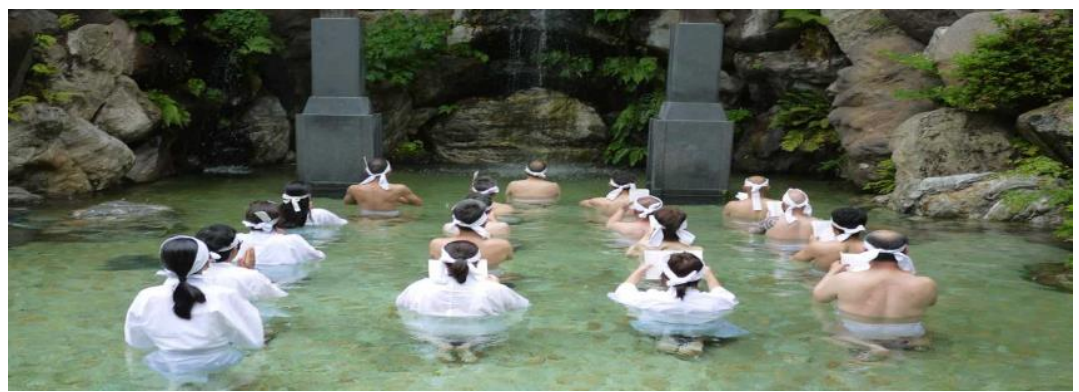

Documentation: kazu1000.wordpress.com

Fig. 3. The participants wearing white loincloths (men) or kimonos (women) and hachimaki as misogi ritual costumes [10]. 
When the participants enter the waterfall area and face the main hall of worship known as Honden, the ritual will begin. They bow twice, clap twice, and bow once more. The next session will consist of some sort of exercise guided by Michi-hiko.

\section{Furitama}

Furitama is the first exercise in the misogi ritual after the warm-up exercises. Participants hold their hands in front of their stomachs and shake them while repeating the words Harae do no okami. They must focus in order to communicate with the kami.

The exercise's purpose is to activate the participants' souls.

\section{Torifune}

Torifune is a hand exercise similar to rowing a boat. This exercise is combined by the furitama and repeated for several times. While performing those exercises, the participants shout "Yie!" followed by "Ei!" and "Ho!" when they turn to the furitama. The position of the left and right front feet alternates as well. They shout "Yie!" and then "Se!" when changing the position of the right foot to the left foot.

The purpose of the torifune is to introduce the physical dimension to the spiritual dimension.

Otakebi

The participants follow the Michi-hiko's invocations with their bodies straightened, feet slightly apart, and hands on their waists. The first three invocations are as follows: Iku Tama! Taru Tama!, Tama Tamaru Tama!

The following invocations are a little longer: Kami! Okami! Kunitsu-Okami! Sarutahiko Okami Ti toshi ya!.

The invocations are shouted to activate the soul (Iku Tama), to affirm awareness (Taru Tama), and to keep the soul activated (Tama Tamaru Tama). The last long invocations was read as a way of acknowledging Sarutahiko Okami's great power as the head of earthly kami.

\section{Okorobi}

The standing position remains unchanged from the previous position. The ritual participants then place their left hand on their waist, followed by two fingers on their right hand pointing forward in a gesture similar to the "Boy Scout Salute."

Michi-hiko shouts the three kami names, which the participants must repeat while demonstrating the hand-cutting gesture with the sword:

Kunitoko tachi no Mikoto! "Yie!"

Sarutahiko no Okami! "Yie!"

Kokuryu no Okami! "Yie!"

The purpose of the okorobi is to unite with the three kami so that their impurities can be removed and they can gain strength from the kami.

\section{Ibuki}

After going through several previous exercises, ibuki is the exercise to regulate the breath. Stretch out the hands and arms while inhaling deeply and slowly exhaling through the mouth to perform ibuki. This exercise should be repeated five times.

Participants then turn to face the waterfall, bow twice, clap their hands twice, stretch their arms, and come down from the waterfall.

Nyusui

Michi-hiko will give purifying salt to the participants at this step. The sake and salt they have received must then be sprayed into the stream three times by mouth. Michi-hiko then recites a prayer made up of nine letters, which are as follows:

Rin pyo to sha kai zin retsu zai zen 
Michi-hiko continued by cutting the air nine times, followed by shouts of "Yei!" The participants then enter the water and spray themselves on the face, chest, and loins.

Michi-hiko ended the ritual with a shout of "Yei!"

\subsection{Recapitulation of The Meaning of Water in Javanese Padusan and Japanese Misogi-Harai Rituals: Similarities and Differences}

Based on the analysis in the previous sub-section, summary in the form of a table can be created to determine the similarities and differences in the meaning of padusan and misogiharai rituals.

Table 1. The Meaning of Water in Javanese Padusan and Japanese Misogi-Harai Rituals: Similarities and Differences.

\begin{tabular}{|c|c|c|c|}
\hline & The Water Meaning & $\begin{array}{c}\text { Padusan } \\
\text { Ritual }\end{array}$ & $\begin{array}{c}\text { Misogi- } \\
\text { Harai Ritual }\end{array}$ \\
\hline 1. & $\begin{array}{c}\text { Purifying the soul from } \\
\text { impurities/sin }\end{array}$ & $\sqrt{ }$ & $\sqrt{ }$ \\
\hline 2. & $\begin{array}{c}\text { The media to obtain God's } \\
\text { power }\end{array}$ & $\mathrm{X}$ & $\sqrt{ }$ \\
\hline 3. & $\begin{array}{c}\text { The media of communication } \\
\text { with God }\end{array}$ & $\mathrm{X}$ & $\sqrt{ }$ \\
\hline 4. & $\begin{array}{c}\text { Returning the spirit to } \\
\text { devotion to God }\end{array}$ & $\sqrt{ }$ & \\
\hline
\end{tabular}

\section{Conclusion}

Based Based on the results of the data analysis, it is possible to conclude that padusan and misogi-harai have similarities in terms of the use of water as a ritual medium. The water in both rituals has a similar meaning: it can be used to purify oneself of impurity/sin. This demonstrates water's properties as an element capable of dissolving impurities, both dirt in the denotative sense and dirt in the connotative sense, which in this case is sin and impurity.

The next similarity in the meaning of water is a medium that can rekindle enthusiasm for God's service. The mind and body are awakened again by the freshness of water that hits the body parts, allowing them to stay awake in serving God.

Padusan and misogi-harai rituals not only have a deep meaning in water as their medium, but they also play a role in preserving environmental sustainability from damage.

\section{References}

1. K. Dijk, et al., Cleanliness and Indonesian Histories Culture (2011)

2. S. Picken, Historical Dictionary of Shinto (2011)

3. A. Paul, et al., Qualitative Research: Theory, Method and Practice (2004)

4. R. Widyastutik, Pandangan Masyarakat mengenai Tradisi Padusan in Tesis Sebelas Maret University (2010)

5. C. Pratiwi, H.T.R.K. 5, 173-185 (2017) 
6. Aditya, Padusan dan Penghargaan pada Alam, www.krjogja.com/angkringan/opini/

7. Diskominfo Boyolali, Tradisi Padusan Sambut Bulan Ramadhan di Boyolali, www.youtube.com/watch?v=tPRIJXOyexU

8. S. Picken, Sourcebook in Shinto: Selected Documents: Selected Documents Resources in Asian Philosophy and Religion (2004)

9. M. Haikal, Tugas-Tugas Shinsoku di Takekoma Jinja in Tesis University of North Sumatera (2019)

10. K. Sakamoto, Misogi (祥)「みそぎ」A Japanese Shinto Practice of Ritual Purification by Washing The Entire Body, kazu1000.wordpress.com/2020/02/27/ 